\title{
NIGERIA-CHINA BILATERAL TRADE RELATIONS: IS THERE MARKET OPPORTUNITIES IN CHINA?
}

\author{
Kabiru Hannafi Ibrahim¹, Dyah Wulan Sari², Rossanto Dwi Handoyo ${ }^{3}$ \\ ${ }^{1}$ Department of Economics, Faculty of Economics and Business, Universitas Airlangga \& \\ Department of Economics, Faculty Arts, Social and Management Sciences, Federal University; \\ email: kabiru.hannafi@fubk.edu.ng \\ ${ }^{2}$ Department of Economics, Faculty of Economics and Business, Universitas Airlangga; \\ email: wulansari@feb.unair.ac.id \\ ${ }^{3}$ Department of Economics, Faculty of Economics and Business, Universitas Airlangga; \\ email: rossanto_dh@feb.unair.ac.id
}

\begin{abstract}
Abstrak
Penelitian ini menggunakan keuntungan komparatif sektoral yang terungkap normalisasi (NRCA), pangsa permintaan impor (IDS), kerangka identifikasi pertumbuhan dan fasilitasi untuk mengidentifikasi peluang pasar bagi Nigeria dalam perekonomian Cina selama periode 1988-2017. Temuan kami mengungkapkan bahwa Nigeria memiliki keunggulan komparatif stabil dan jangka panjang dalam beberapa komoditas dan ada ruang terbatas bagi Nigeria untuk meningkatkan neraca perdagangan karena potensi ekspor yang terbatas. Selanjutnya, enam belas peluang pasar diidentifikasi, di mana empat belas adalah pasar yang stabil dan berkembang. Temuan kami juga mengungkapkan bahwa peluang pasar ini tidak semuanya dapat dipenuhi oleh Nigeria, karena komoditas ini tidak dapat diekspor karena posisi kompetitif yang buruk dan sifat komoditas yang sangat padat modal. Temuan-temuan ini tidak hanya relevan bagi akademisi tetapi juga untuk pembuatan kebijakan.
\end{abstract}

Keywords: IDS, Nigeria-Cina, NRCA, peluang pasar, potensi ekspor

\begin{abstract}
This study used normalized revealed sectoral comparative advantage, import demand share, growth identification and facilitation framework to identify market opportunities for Nigeria in the Chinese markets over the period 1988-2017. Our findings revealed that Nigeria has a steady and long-term comparative advantage in few commodities and there is limited scope for Nigeria to improve on its balance of trade due to limited export potentials. Furthermore, sixteen market opportunities were identified, out of which fourteen are stable and growing markets. Our findings also revealed that these market opportunities can't all be meet by Nigeria, as these commodities were not exportable due to poor competitive position and highly capital-intensive nature of the commodities. These findings are not only relevant to academics but also for policy making.
\end{abstract}

Kata Kunci: export potentials, IDS, market opportunities, Nigeria-China, NRCA 


\section{Introduction}

In the whole African continent, Nigeria has remained one of the major Chinese trading partners, as it provides a huge market for various Chinese products such as electrical machinery and equipment, vehicles, railway tram and roll-stock, aluminum, nuclear reactors and boilers, furniture, bedding, mattress, cushion among others (UN Comtrade, 2018). Nigeria-China diplomatic relations all started in 1971 with an emphasis on scientific and technological cooperation. However, Nigeria-China bilateral relations became heavily affected during Nigeria's military rule and it was not until Nigeria regained her democracy that bilateral cooperation between the two countries began to develop. Due to the setback of Nigeria-China trade relations during Nigeria's military regime, Nigeria-China Chamber of Commerce and Industry was established in 1994 as a step toward revamping bilateral cooperation between the two countries. The regained of Nigeria's democracy and subsequent trade liberalization reforms that followed have paved the way for China's entry into the Nigerian economy. Nigeria and BRICS trade relations (of which China is among) has also been on the rise as a result of Nigeria's oil and other opportunities in the country (Alao, 2011). Given these trade relations, the rise of the Chinese economy has changed the direction of Nigeria's the trade and investment from its traditional trading and investment partners such as the United States (US) and Western Europe (WE) toward China, India, and Brazil. This is contrary to the trade alliance between Nigeria and its traditional trading partners which have come a long way, but yet it is debatable if such alliance has yielded any significant result to Nigeria's economy (Ogunkola et. al., 2008).

The recent increase in Chinese investment in Nigeria provides an alternative source of external finance to Nigeria. This must not be unconnected with the agreement signed between the two countries on the establishment of China Investment Development and Trade Promotion Centre in Nigeria and Nigeria Trade Office in China. The operations of Chinese companies within Nigeria's territory especially in areas of oil and gas, electric power, construction, real estate, and telecom have further strengthened bilateral cooperation between the two countries; to which many have argued that Chinese presence in the Nigerian economy is to exploit Nigeria's resources as did by the Western world. This, however, seems not to be true given the pattern and mode of Chinese investment in Nigeria as clearly shown by investment data (Ayodele \& Sotolo, 2014). 
In areas of trade, trade between Nigeria and China has now become more pronounced and it has remained the main channel of boosting economic cooperation between the countries. China is top Nigeria's import origin and as such in terms of import China is top Nigeria's trading partner. Nigeria-China bilateral trade hits $\$ 10.62$ billion in 2016. This shows a more than 59 times increase in total bilateral trade over the last two decades. The trade balance that exists between the two countries in 2017 was put at $\$ 10.53$ billion in favour of China (UN Comtrade, 2018). This trade imbalance is attributed to the oil and manufacturing sectors which characterized Nigerian and Chinese economies respectively (Eneji et. al. 2012). Over the last few years among its major trading partners, Nigeria has incurred the highest trade deficit with China. Despite this trade imbalance, Ekesiobi et. al. (2011), have maintained that bilateral trade has not lead to increased exploitation, unfair cooperation and unhealthy trade between the two countries. Figure 1, depicts the widening deficit trade balance which has bedeviled Nigeria over the period 1988-2017.

Figure 1 - Trends in Nigeria's trade balance with China 1988-2017.

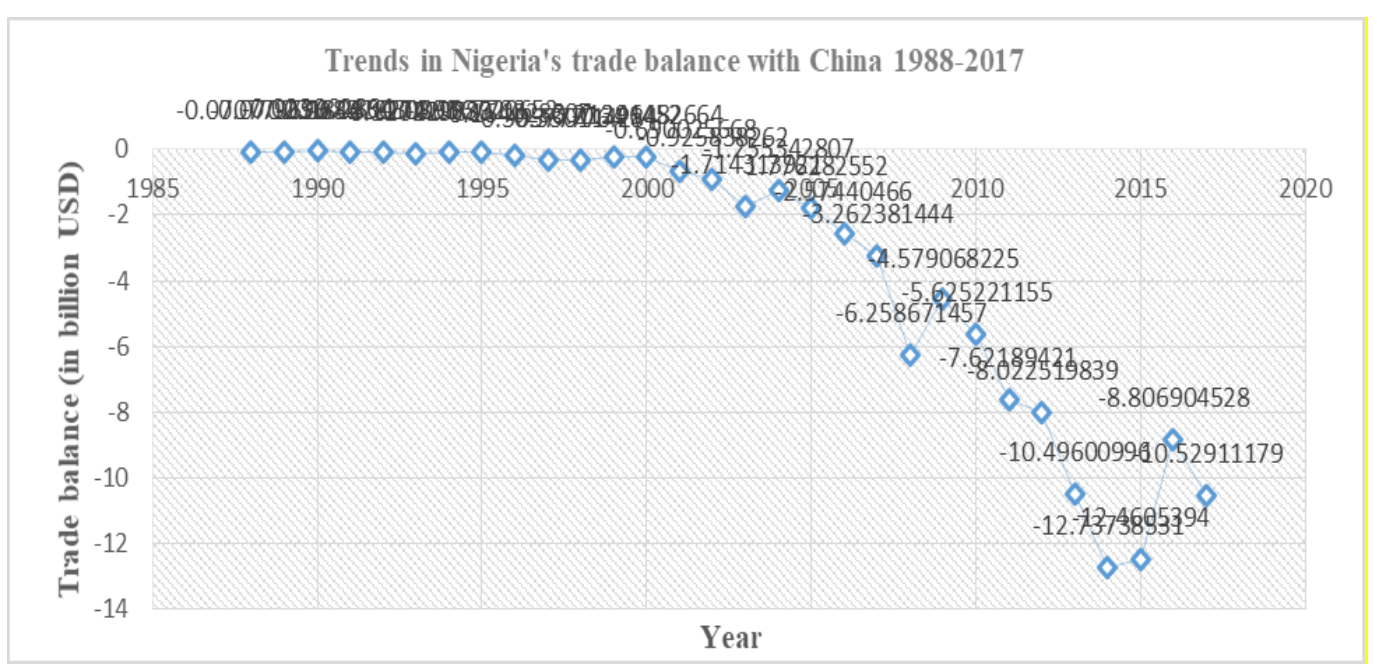

Source: Authors' computation from UN Comtrade Statistics.

Figure 1 shows that over the study period Nigeria's export to China has trailed behind its import. This trade imbalance has not only grown but also worsen. This is because there was never been a trade balance at Nigeria's advantage. However, as China is the key import origin for Nigeria, this represents a serious threat to Nigeria's efforts aimed at diversifying its export to reduce its perpetual unfavourable trade balance. Given the scenario depicted in figure 1 , it is worth noting that, the pattern of Nigeria-China trade 
is not in line with Nigeria's pursuit to diversify its export to China and the rest of the world. This implies that diversifying Nigeria's export to China will be an arduous task considering the structure of Chinese exports which are mostly manufactured goods. The balance of trade (BoT) has also been in favour of China as there was never been a balance of trade in favour of Nigeria for several decades. Figure 1, demonstrates Nigeria's export to China was very impressive based on the recent trade data coupled with a decline in its perpetual deficit trade balance from 2014 to 2016 though it has increased in 2017.

Despite the growing trade between Nigeria and China coupled with overwhelming deficit BoT recoded by Nigeria over several decades, in recent times empirical studies have not been conducted to identify areas of opportunity and ways that could help Nigeria increase its export to China and lessen/eliminate its deficit trade balance. This has called for the need to conduct this study and identify commodities with which Nigeria can export to China, to bridge its overwhelming deficit BoT. In the same vein, the study also sought to identify new market opportunities for Nigeria in the Chinese economy based on the growth in Chinese major imports demand and commodities with which Nigeria has the potentials and capacity to export. A study of this nature within the context of NigeriaChina trade has not been conducted in any empirical study, as such this study is a novel empirical work, as we are first to conduct this kind of study. We applied a simple methodological approach comprising the use of a normalized version of Revealed Sectoral Comparative Advantage (NRCA) formula, Import Demand Share (IDS) and elements of Growth Identification and Facilitation Framework (GIFF), to achieve the stated objectives which to our knowledge has not been applied to any empirical study of Nigeria-China bilateral trade relations. With this in mind, this study contributes to the few existing empirical kinds of literature of trade more especially Nigeria-China bilateral trade relations.

To achieve the stated objectives the rest of the paper is structured as follows: Section 2 reviews both theoretical and empirical literature. Section 3 discusses the data sources and methodology. Section 4 presents the results and analysis and section 5 concludes the paper and offered policy recommendations. 


\section{Literature review}

\section{Theoretical review}

In trade literature, mercantilism has been one of the trade theories that is predominantly used even today because of its great emphasis on accumulating "specie" (surplus of gold and silver) through global trade. The most prominent founder of mercantilist thought in that era was Thomas Mun (1571- 1641), who is a merchant from London England. The main views of mercantilists represent the interest of trader (merchants), businesses and have flourished during the sixteenth, seventeenth, and the eighteenth centuries. The whole idea of mercantilism rest on the belief that surplus realized through foreign trade is the main source of the country's wealth, and this is accumulated mainly in the form of gold and silver. Mercantilists saw the importance of bullion accumulation for the continued existence of countries and emphasized on the role of foreign trade to acquire riches and national wealth rather than through conquest. Mercantilists argued that the government should form trade policies that would lead to a trade surplus rather than a deficit. They believed that surplus if realized through trade could result in more wealth and increase the flow of "specie" into the country than going out. During the 1600s and 1700s, Western Nations have considered mercantilists views as a prescription for national progress. The adoption of mercantilists' policies by countries such as England, France and Spain has become the basis for the creation of trade restriction policies such as quota and import duties to prohibit and discourage the import of certain goods.

The major drawback of mercantilists' theory is that the theory has a narrow view of trade as zero-sum game i.e. a game of winners and losers, ignoring the fact that international exchange is a business transaction from which both countries involved could benefit. This theory despite its flaws which has been recorded in history is still considered relevant by many countries even today. This is because most countries nowadays were favouring exports and prohibiting imports in certain circumstances. Nigeria and China were no exception in this regard. In the case of Nigeria and its perpetual unfavourable trade balance, the modern-mercantilism approach could help in reducing its trade deficit with China. Since 2015 Nigeria has sought to decrease imports and devalue currency which is part of its modern mercantilism policy to increase exports to China and the rest of the world. This policy has only recorded very limited success in reducing its trade deficit with China in the years 2016 and 2017. China in the whole world has been at the 
forefront of modern mercantilism because of its industrial policy through subsidy and currency devaluation to increase exports. Chinese mercantilism policy has also contributed to widening the long period trade deficit on the part of Nigeria. Through its modern mercantilism policy, China has succeeded in making its exports more competitive in the whole world. In which case, Nigeria despite its policy toward modern mercantilism will find it difficult to bridge its trade deficit by increasing exports to China. This is because, for several decades, the growth in Nigeria's foreign markets and product exported to those markets have not been so impressive coupled with limited export potentials and mono-cultural nature of its economy (Ibrahim \& Yusuf, 2017). Modern mercantilism policy could help Nigeria to diversify its export to China and improve on its trade balance in as much as, there are market opportunities in China and export potentials on the part of Nigeria. In the context of Nigeria-China trade relations, mercantilist trade theory is important is explaining the scenario of their trade. This is because the theory saw the success of trade among these countries by the size of their trade balance and that Nigeria and China were striving toward this success.

In another perspective, Smith (1776) have argued against the mercantilist trade theory. Smith has argued that free trade among nations is one of the mechanisms to increase countries' wealth and welfare. He further argued that free trade encourages the division of labour and specialization which increases the scope of goods and services to be consumed by trading nations. His "Absolute Advantage Theory" which was derived from his book "An Inquiry into the Nature and Causes of Wealth of Nations" saw the need for the country to specialize in the production and exportation of those goods and services which it can produce at a lower cost than other countries and exchange the surplus with other goods and services produced by other countries more cheaply than it can produce. In this case, as pointed out by Smith both countries enjoyed the benefit of absolute cost advantage since they can produce more of one goods and services than the other countries with fewer resources. Smith (1776) saw the need for countries to increase trade through market forces, and that government policy should not regulate trade in any way. An attempt to regulate trade to maintain a favourable trade balance is superfluous because it is counter-productive. The shortcoming of absolute advantage theory is that countries who in certain goods and services do not have absolute cost advantage will not gain any benefit of specialization. In this case, in any line of activity, least developed and 
developing countries with unskilled labour and inefficient machinery may not gain from an absolute cost advantage.

In the early part of the 19th century, Ricardo (1817) extends Smith argument of free trade doctrine and proposed a theory of the gains from trade known as a comparative advantage cost which centered on the relative opportunity cost of production rather than absolute cost as Smith had advanced. Ricardo contended that country should import a commodity even if it is more efficient in the production of that commodity than the country from which it is importing. The theory is to some extent based on labour theory and that market prices are determined by relative labour cost used in their production. To these end, less productive countries can gain from international trade by trading with their productive neighbours and that countries with low wages are unlikely to use their low production cost at their advantage in any situation. The major conclusion of the Ricardian model is that with free international exchange, every country can benefit from trade. The major shortcoming of Ricardo's theory is that it neglected the role of demand in trade theory until Mill introduced "Reciprocal Demand" which was later advanced by Marshall (Sen, 2012).

Based on the aforementioned objectives of this study, these theories were relevant to this study as they all laid a solid foundation for the recent developments in global trade. The mercantilist theory is still used as a model by countries to maximize trade gains and increased welfare and as such countries that produce goods with high and increasing foreign demand tend to export more and record favourable trade balance as observed by this theory. The theory is also relevant to this study, as the study focused on investigating commodities with high and increasing market demand in the Chinese economy that could help Nigeria increase its export to China and gains more from trade. In a world of increasing competition, Smithian and Ricardian trade model of absolute and comparative advantage are also relevant to this study. To Smith, the gains from trade can only be realized by promoting both export and import which would result in more competitive and freer trade that could increase demand and supply at the global level and ensure sustained equilibrium.

\section{Empirical Review}

There are a few empirical studies conducted on Nigeria-China bilateral trade relations. Some of these studies include; Nabine (2009) investigated the impact of Chinese 
investment and bilateral trade flow on Nigeria's economic growth. The finding showed that bilateral trade doesn't contribute to Nigeria's economic growth in the short-term, while in the long-term it can affect and contribute to economic growth. Eneji, et. al. (2012) while analyzing the effect of Nigeria's trade balance with China on the textile industry, revealed the need for private sector investment to make the Nigerian textile industry more internationally competitive. Ayoola (2013) found that due to the high rate of import from China by Nigeria, there exists a trade imbalance in favour of China and with the emergence of China as world super-power Nigeria stands a better chance to gain from China's model of growth, manufacturing and investment expertise. Pant \& Pande (2014) examined the dynamic of trade in pharmaceutical among China, India, Pakistan, and South Asia Free Trade Area Agreements. The study revealed that favourable tariff treatment to China may have an effect on India's low trade-in pharmaceutical products with Pakistan. Hammerstad (2011) showed that Nigeria's relations with emerging global powers including China are influenced by its internal policy, the international policy of the emerging global powers and Nigeria's abundance of human, natural and economic resources.

Other similar studies include (Ibrahim \& Iorember 2018; Ibrahim \& Sari 2019a), that examined the trends, composition, trade intensity and identified sectors and commodities with a comparative advantage in Nigeria-China trade relations. These studies revealed a limited scope for Nigeria to increase its exports to China based on its comparative advantage and reduce its deficit BOT. Another strand of studies includes (Ibrahim, 2015; Ibrahim \& Abdulaziz, 2016; Ibrahim \& Sari, 2019a; Ibrahim \& Sari, 2019b; Ibrahim \& Sayuti, 2017a), that examined the comparative advantage and measure the extent to which Nigeria's export supply match with China, Brazil, and India import demand. Results from these studies showed that Nigeria can only competitively export mineral fuels while China, Brazil and India can export competitively numerous products to Nigeria and there is a partial match between Nigeria's export supply and their import demand. Ibrahim \& Singh (2014) analyzed Nigeria-India bilateral trade and found that India's import intensity is less intense from 2001 to 2005, while in the years 2000 and 2006-2012 it has high intense value. The trade and export intensity is high intense over the study period 2000-2013. Ibrahim \& Sayuti (2017b) have examined Nigeria's trade with West African countries and found high trade intensity in Nigeria's trade with Benin, Cote d'Ivoire, Ghana, Senegal, and Togo. The result further indicated that Nigeria can 
export raw hides and skins, cocoa and mineral fuels to countries with low comparative advantage. Ibrahim \& Yusuf (2017) have shown that over 60 percent of Nigeria's exports go to highly concentrated and non-diversified markets coupled with non-diversified exportable commodities thereby impeding export potentials and diversification.

Based on the foregoing literature there are two lines of studies on Nigeria-China bilateral trade. The first line of literature focused on the determinants of bilateral trade between Nigeria and China while the second line is more focused on exploring the commodities traded between the countries. Studies with an emphasis on identifying new market opportunities for Nigeria in the Chinese economy based on comparative advantage, IDS and growth in import demand were not available, as we could not trace a single study that focuses on such issue. As far as Nigeria and China bilateral trade relation is concerned we argued that this is a gap in the literature that needs to be filled considering the worsening deficit BOT disfavouring Nigeria.

The role of the determinants of bilateral and multilateral trade relations remained as provided by trade literature and there exists numerous literature on this line of research. With recent advancement in technological development factors determining trade should not only be relied upon as a basis of trade policy aim at bridging deficit balance of payment (BoP) and BoT. For instance, exchange rate, distance, common border and other geographic determinants of trade are less strong determinants of trade nowadays. However, an exchange rate policy which aimed at increasing exports may not be successful if there are no market opportunities in a country's trading partner's economies. Again, the role of distance in determining trade has drastically been reduced by the use of technology like the internet. The similarity of trade structure among geographically closed countries has also reduced the volume of trade among these countries and increased their trade with more distanced nations. As noted by Amavilah (2003), most countries in Africa share borders and yet trade between and among the countries is almost zero. Therefore, countries can trade more or less for reasons other than the traditional determinant of bilateral trade. In line with this, we further argued that to improve trade balance for a country experiencing a worsening deficit trade balance there is a need to identify commodities and market opportunities in its trading partners' economy for which it can export and improve on its BoT. It is based on this line of argument and literature gap upon which this study has been conducted. 


\section{Methodology}

The data about the variables used in this study were collected from the United Nations Commodity Trade Statistics (UN Comtrade) database and accessed via World Integrated Trade Solution (WITS). The study used data from 1988-2017 and analyzed Nigeria-China NRCA, IDS and GIFF. Data were collected at Harmonized Section HS 2 digit codes covering 97 categories of commodities.

Twenty major product categories were chosen and analyzed to determine areas of complementarity and similarity in Nigeria and China trade. So also 16 major commodities were identified as market opportunities for Nigeria in Chinese markets. The identification of these commodities was completed using IDS and Mean Average Share (MAS). The selection and identification of market opportunities were conducted after smoothing the data, through the use of 5-year Exponential Moving Average (EMA) method that is known to filter out any noise from cyclical fluctuations and to avoid bias selection and market identification.

The measure of comparative advantage used in trade literature is the Revealed Comparative Advantage (RCA) put forward by Balassa (1965). This index has drawbacks as pointed out by Benedictis (2005). As a result, this study used a modified version of RCA as proposed by Benedictis (2005), to solve the problem associated with RCA. RCA index is expressed as; RCAit $=(X i j / X t j) /(X i w / X t w)$

Where $\mathrm{RCA}_{\mathrm{it}}=$ revealed comparative advantage index of product $_{\mathrm{i}}$ at time $\mathrm{t}, \mathrm{X}_{\mathrm{ij}}=$ is the export of product ${ }_{i}$ from country ${ }_{j}, X_{t j}=$ is total exports from country ${ }_{j}, X_{i w}=$ World's export of product ${ }_{i}, X_{\mathrm{wt}}=$ World's total export. RCA lies between 1 and . $(\mathrm{RCA}>1)$, indicate comparative advantage, while if the value lies between 0 and 1 , it is considered as a comparative disadvantage. $<1$ and $>1$ are not symmetrical in which case the distribution of indices is skewed and this affects the conclusion on the comparative advantage of commodities. As a result we used the modified version proposed by Benedictis (2005), which is: $N R C A=(R C A-1) /(R C A+1)$

This corrected for the asymmetry bias of RCA and also reduced the RCA index to $(-1,0)$ and $(0,1)$. If NRCA index is between 0 and 1 it implies comparative advantage and between -1 and 0 is a comparative disadvantage.

The study further used elements of GIFF developed by Lin \& Monga (2011), IDS and MAS for commodities imported to identify market opportunities for Nigeria in the Chinese market. 
Using this methodology, we postulated that a market opportunity exists in China if a commodity IDS is greater than or equal to its MAS in the total Chinese import, irrespective of the short and long-term growth in the total import. The MAS is defined as the total import share (which must be 1 or 100\%) of all commodities imported by China and divided by the number of commodities imported by China at the HS 2 digit codes. In our case, it is given by; MAS $=100 /$ Number of Commodities Imported

At HS 2 digit codes China imports 97 categories of commodities, therefore, in this case, MAS for each product is $($ MAS $=100 / 97)=1.03$. MAS value of 1.03 shows the mean share of a given commodity in total import under the case of equal import share for all commodities imported. A market opportunity exists for a commodity if it's IDS or simply actual import share is greater than or equal to its MAS of 1.03. Therefore, any commodity with IDS below 1.03, we assumed that there is no market for such commodities in China. Based on these criteria, in table 2, 16 commodities were identified as commodities with market opportunities in China. So also any commodity that featured among the commodities with high IDS and not in the top major 20 commodities analyzed in table 1 is the new market opportunity for Nigeria in China. Based on the study findings in table 2 there exists 9 new markets opportunity for Nigeria in China. So also table 3 , shows that of the seven commodities with which Nigeria can export to China four possessed lower market demand in the Chinese economy as their IDS are less than the MAS of 1.03 in column 4. Therefore, our entire analysis will be based on the results depicted in tables 1,2 , and 3 .

Table 1 - Nigeria-China Mean NRCA Index in 20 Major Products based on HS-2 Digit Codes 19882017.

\begin{tabular}{|l|c|c|}
\hline Products Description & Nigeria & China \\
\hline Aluminum and articles thereof & -0.77 & -0.07 \\
\hline Articles of iron or steel & -0.95 & 0.19 \\
\hline Cocoa and cocoa preparations & 0.66 & -0.87 \\
\hline Cotton & -0.40 & 0.35 \\
\hline Electrical Machinery \& equipment, parts thereof; \& sound recorder & -0.99 & 0.31 \\
\hline Explosive; pyrotechnic prod; matches; alloy; etc. & 0.71 & 0.32 \\
\hline Fish, crustacean \& other aquatic invertebrate & -0.56 & -0.02 \\
\hline Footwear, gaiters and the like; parts of such articles & -0.77 & 0.55 \\
\hline Furniture; bedding, mattress, cushion, etc. & -0.97 & 0.46 \\
\hline
\end{tabular}




\begin{tabular}{|l|c|c|}
\hline Glass and glassware & -0.89 & 0.17 \\
\hline Inorganic chemical compounds and radioactive elements & -0.91 & 0.04 \\
\hline Lac; gums, resins \& other vegetable saps \& extracts. & 0.36 & 0.03 \\
\hline Man-made staple fibers & -0.73 & 0.35 \\
\hline Mineral fuels, oils \& product of their distillation & 0.75 & -0.76 \\
\hline Natural/cultured pearls, precious stones, metals, coin, etc. & -0.96 & -0.34 \\
\hline Nuclear reactors, boilers & -0.97 & 0.14 \\
\hline Oilseed, oleagi fruits; miscellaneous grain, seed, fruit, etc. & 0.13 & -0.46 \\
\hline Organic chemicals & -0.97 & -0.13 \\
\hline Raw hides and skins \& leather & 0.53 & -0.55 \\
\hline Rubber and articles thereof & 0.25 & -0.11 \\
\hline
\end{tabular}

Sources: Authors' Computation from UN Comtrade.

Table 1 shows the mean competitive position of twenty major products exported by Nigeria and China over the period 1988-2017. In the case of Nigeria, the comparative advantage indices are positive for the following commodities; cocoa and cocoa preparations, explosive; pyrotechnic matches and alloy, etc., lac; gums, resins and other vegetables, mineral fuels, oils and product of their distillation, oilseed, oleagi fruits, grain, seed, fruit, etc., raw hides and skins and leather and rubber and articles thereof. The negative indices imply comparative disadvantage and are for commodities like aluminium and articles thereof, articles of iron or steel, cotton, electrical machinery and equipment, parts thereof; and sound recorder, fish, crustacean and other aquatic invertebrate, footwear, gaiters and the like, furniture; bedding, mattress, cushion, etc. glass and glassware, inorganic chemical compounds and radioactive elements, man-made staple fibers, natural/cultured pearls, precious stones, metals, coin, etc., nuclear reactors, boilers, organic chemicals, rubber and articles thereof. Since the indices are computed based on the mean or average NRCA over the period 1988-2017 it implies that Nigeria has a longterm and steady comparative advantage in commodities with positive NRCA and comparative disadvantage in commodities with negative NRCA. The mean NRCA index in the case of China is positive for commodities such as articles of iron or steel, cotton, electrical machinery and equipment, explosive; pyrotechnic matches and alloy, etc., footwear, gaiters and the like, furniture; bedding, mattress, cushion, etc., glass and glassware, inorganic chemical compounds and radioactive elements, lac; gums, resins and other vegetables, man-made staple fibers and nuclear reactors, boilers. 
China enjoyed more comparative advantage than Nigeria as it can potentially export most of the analyzed commodities to Nigeria, while Nigeria has a comparative advantage in only seven commodities. The comparative advantages which Nigeria enjoyed are more significant than that of China. This is because the indices are higher except for oilseed, oleagi fruits, grain, seed, fruit, etc. In term of scope and potential of increasing bilateral trade relations between the two countries, based on the result obtained, Nigeria can competitively export to China commodities like cocoa and cocoa preparations, explosive; pyrotechnic matches and alloy, etc., lac; gums, resins and other vegetables, mineral fuels, oils and product of their distillation, oilseed, oleagi fruits, grain, seed, fruit, etc., raw hides and skins and leather and rubber and articles thereof. There is little scope of increasing trade between the two countries in explosives; pyrotechnic matches and alloy etc., lac; gums, resins and other vegetables as they all have a comparative advantage in these products. The value of NRCA indices are negative for both countries in aluminium and articles thereof, fish, crustacean and other aquatic invertebrate, natural/cultured pearls, precious stones, metals, coin, etc. organic chemicals, implying that they all have a comparative disadvantage with no scope of increasing their trade-in these commodities. But there is a greater scope of increasing their trade with other countries that have a comparative advantage in these commodities. There is a high potential of expanding Chinese export to Nigeria as China can competitively export to Nigeria commodities like articles of iron or steel, cotton, electrical machinery and equipment, footwear, gaiters and the like, furniture; bedding, mattress, cushion, etc. glass and glassware, inorganic chemical compounds and radioactive elements, man-made staple fibers, nuclear reactors, boilers.

\section{Market Opportunities for Nigeria in the Chinese Economy}

Based on the revealed sectoral comparative advantage results, it was found that China enjoyed a more comparative advantage than Nigeria. Nigeria only enjoyed a comparative advantage in fewer products. This is coupled with the overwhelming deficit trade balance which has for long been disfavouring Nigeria as clearly depicted in figure 1 . There is very limited scope for Nigeria to improve on its current balance of trade as there are limited export potentials to China. It has been part of the objectives of this study to identify market opportunities for Nigeria in the Chinese market based on share and growth in 
Chinese major import demand and commodities with which Nigeria has the capacity and potential to export.

Table 2 - Market Opportunities, Average Import Growth and Share in Total China's Import

\begin{tabular}{|c|c|c|c|}
\hline $\begin{array}{l}\text { Market opportunities for } \\
\text { Nigeria in China }\end{array}$ & $\begin{array}{l}\text { Average long term } \\
\text { growth 2008-2017 }\end{array}$ & $\begin{array}{l}\text { Average short term } \\
\text { growth 2015-2017 }\end{array}$ & $\begin{array}{c}\text { Average share in } \\
\text { total import } 2015 \\
2017\end{array}$ \\
\hline $\begin{array}{l}\text { Aircraft, spacecraft, and parts } \\
\text { thereof }\end{array}$ & 15.33 & -0.16 & 1.30 \\
\hline Copper and articles thereof & 5.83 & 0.64 & 2.81 \\
\hline $\begin{array}{lll}\text { Electrical machinery } & \& \\
\text { equipment } & & \end{array}$ & 7.29 & 1.07 & 20.61 \\
\hline Iron and steel & -1.14 & 1.89 & 1.54 \\
\hline $\begin{array}{l}\text { Mineral fuels, oils \& product of } \\
\text { their distillation }\end{array}$ & 4.75 & 2.57 & 15.92 \\
\hline $\begin{array}{l}\text { Natural/cultured pearls, } \\
\text { precious stones, metals, coin, } \\
\text { etc. }\end{array}$ & 77.59 & -3.27 & 2.40 \\
\hline Nuclear reactors, boilers & 1.62 & 0.98 & 9.63 \\
\hline $\begin{array}{l}\text { Oilseed, oleagi fruits; } \\
\text { miscellaneous grain, seed, fruit, } \\
\text { etc. }\end{array}$ & 9.07 & 1.13 & 2.41 \\
\hline $\begin{array}{l}\text { Optical, photo, cine, checking, } \\
\text { precision, etc. }\end{array}$ & 4.22 & 0.16 & 5.96 \\
\hline Ores, slag and ash & 4.72 & 3.50 & 7.85 \\
\hline Organic chemicals & 4.20 & 1.68 & 3.55 \\
\hline Plastics and articles thereof & 4.36 & 0.60 & 4.27 \\
\hline $\begin{array}{l}\text { Pulp of wood/of other fibrous } \\
\text { cellulosic mat; waste etc. }\end{array}$ & 7.30 & 1.76 & 1.12 \\
\hline Rubber and articles thereof & 5.79 & 3.33 & 1.13 \\
\hline $\begin{array}{l}\text { Vehicles railway tram and roll- } \\
\text { stock }\end{array}$ & 19.44 & 1.38 & 4.27 \\
\hline $\begin{array}{l}\text { Wood and articles of wood; } \\
\text { wood charcoal. }\end{array}$ & 19.22 & 2.56 & 1.10 \\
\hline
\end{tabular}

Sources: Authors' Computation from UN Comtrade. 
Table 2 depicts sixteen commodities that were found to be commodities with high import demand based on their IDS as shown in the fourth column of table 2 which all exceeded our computed MAS of 1.03. The trend in short and long term growth of these imports demand are also shown in column 2 and 3. Unlike in the case of short-term growth, the long-term growth of China's major import demand has remained reasonably remarkable and positive except for iron and steel with negative growth. The long-term growth shows that China's import has moderately grown for most of the products. The short-term growth rate was low for all commodities and even negative for aircraft, spacecraft, and parts thereof, natural/cultured pearls, precious stones, metals, coin, etc. In the last two years of our sample period, China's most dominant and major imports demand were electrical machinery and equipment, mineral fuels, oils and product of their distillation, nuclear reactors and boilers, ores, slag and ash, optical, photo, cine, checking and precision among others which accounted for the highest share of $20.61 \%, 15.92 \%$, $9.63 \%, 7.85$ and $5.96 \%$ in the total Chinese imports. These commodities were vital and prominent in the Chinese imports over the study period as they all account for shares that exceeded the minimum average. Of all these products that were found to be a promising market for exporting countries seeking market opportunity in the Chinese economy, and based on the NRCA result, Nigeria can only potentially supply and export mineral fuels, oils, and products of their distillation, oilseed, oleagi fruits; miscellaneous grain, seed, fruit, etc. rubber and articles thereof. However, table 2 clearly shows that there exists a stable and growing market in 14 of the identified commodities and declining market in two commodities based on average short-term growth. Can Nigeria meet the demand of the identified markets/commodities in China even outside the scope of 20 analyzed commodities? We explored Nigeria's export potential beyond the 20 analyzed commodities and found that Nigeria doesn't have the potential to supply to China and improve on its export position. Nigeria is lacking the potential to serve the growing markets in China based on the computed negative export potential (the table not reported).

Table 3 - Nigeria's Actual and Potential Export to China based on NRCA

\begin{tabular}{|c|c|c|c|}
\hline $\begin{array}{c}\text { Nigeria's actual and } \\
\text { potential exports }\end{array}$ & $\begin{array}{c}\text { China's average long } \\
\text { term growth 2008-17 }\end{array}$ & $\begin{array}{c}\text { China's average short } \\
\text { term growth } 2015-17\end{array}$ & $\begin{array}{c}\text { China's average } \\
\text { share in total } \\
\text { import 2015-17 }\end{array}$ \\
\hline
\end{tabular}




\begin{tabular}{|l|c|c|c|}
\hline $\begin{array}{l}\text { Cocoa and cocoa } \\
\text { preparations }\end{array}$ & 11.05 & 1.13 & 0.05 \\
\hline $\begin{array}{l}\text { Explosive; pyrotechnic } \\
\text { prod; matches; alloy; etc. }\end{array}$ & 39.51 & 1.09 & 0.01 \\
\hline $\begin{array}{l}\text { Lac; gums, resins \& other } \\
\text { vegetable saps \& extracts. }\end{array}$ & 13.37 & 1.31 & 0.01 \\
\hline $\begin{array}{l}\text { Mineral fuels, oils \& } \\
\text { product of their distillation }\end{array}$ & 4.75 & 2.57 & 15.92 \\
\hline $\begin{array}{l}\text { Oilseed, oleagi fruits; } \\
\text { miscellaneous grain, seed, } \\
\text { fruit, etc. }\end{array}$ & 9.07 & & 2.41 \\
\hline $\begin{array}{l}\text { Raw hides and skins \& } \\
\text { leather. }\end{array}$ & 0.11 & -2.46 & 0.44 \\
\hline Rubber and articles thereof & 5.79 & 3.33 & 1.13 \\
\hline
\end{tabular}

Sources: Authors' Computation from UN Comtrade.

Table 3 shows Nigeria's actual and potential exports which were based on its comparative advantage. Seven commodities were found to be the actual and potential export for Nigeria based on the analyzed 20 major product categories. Nigeria's export potentials are not only limited to these commodities identified based on HS 2 digit codes as they may also include new products with which the country can produce and export. These products were placed along with China's long and short-term average import growth and import demand share to identify the growing market and current market opportunities. The long-term import growth rate in China for Nigeria's actual exports are all positive with explosive; pyrotechnic prod; matches; alloy; being the commodity with highest long-term growth of $39.51 \%$. The short-term import growth rate which is an indication of the current growth in potential markets for these products were all positive except for raw hides and skins and leather which is negative. Mineral fuels, oils and products of their distillation, rubber and articles thereof were the commodities with the highest short-term growth of $2.57 \%$ and $3.33 \%$. The current market condition for most of the commodities in China which Nigeria can actually and potentially export to China revealed that there are no market opportunities in these commodities. For instance, commodities like cocoa and cocoa preparations, explosive; pyrotechnic prod; matches; alloy; etc., lac; gums, resins and other vegetable saps and extracts, raw hides and skins has low market demand in China and there is no market opportunity for these products as their (IDS < MAS = 1.03). In case of mineral fuels, oils and product of their distillation, 
oilseed, oleagi fruits; miscellaneous grain, seed, fruit, etc., rubber and articles thereof Nigeria can actually and potentially export these products to China and there are market opportunities based on import demand share and future market potential based on longterm average growth in import.

Therefore, to sum up, the results in Tables 2 and 3, the study identified sixteen commodities for which there are market opportunities in China. As we have demonstrated earlier a market opportunity exists for these commodities because their import demand share is greater than their mean average share (IDS > MAS). The IDS's for these commodities are all greater than MAS $=1.03$ as shown in column 4 of Table 2 . A market opportunity exists in China, in commodities like aircraft, spacecraft, and parts thereof, copper and articles thereof, electrical machinery and equipment, iron and steel, mineral fuels, oils and product of their distillation, natural/cultured pearls, precious stones, metals, coin, etc., nuclear reactors, boilers, oilseed, oleagi fruits; miscellaneous grain, seed, fruit, etc., optical, photo, cine, checking, precision, etc., ores, slag and ash, organic chemicals, plastics and articles thereof, the pulp of wood/of other fibrous cellulosic mats; waste, etc., rubber and articles thereof, vehicles railway tram and roll-stock, wood and articles of wood; wood charcoal. But Nigeria except for mineral fuels, oils and products of their distillation, oilseed, oleagi fruits; miscellaneous grain, seed, fruit, etc., rubber and articles thereof can't export the remaining thirteen commodities. For mineral fuels, oils and products of their distillation, oilseed, oleagi fruits; miscellaneous grain, seed, fruit, etc., rubber and articles thereof there is a market opportunity in China and Nigeria is already serving the market well as such it is not a new market opportunity.

Aircraft, spacecraft, and parts thereof, copper and articles thereof, iron and steel, optical, photo, cine, checking, precision, etc., ores, slag and ash, plastics and articles thereof, the pulp of wood/of other fibrous cellulosic mat; waste, etc., vehicles railway tram and roll-stock, wood and articles of wood; wood charcoal were newly identified market in China for which Nigeria can serve if it can export them based on its comparative advantage and export potential. But unfortunately, these new market opportunities in China can't all be meet by Nigeria as these commodities were either not exportable due to poor competitive position and lack of comparative advantage in the world market or due to the fact that these commodities were a highly capital-intensive product that can only be manufactured and exported by highly capital endowed countries. Therefore, 
Nigeria has no comparative advantage in all of the newly identified markets/commodities. These findings provide support for studies (Ibrahim \& Iorember, 2018; Ibrahim \& Sari, 2019a) that revealed a limited scope for Nigeria to increase its export to China based on only comparative advantage.

\section{Conclusion and recommendations}

In the whole African continent, Nigeria has remained one of the major Chinese trading partners, as it provides a market for various Chinese products. The rise Nigeria-China trade has changed the direction of Nigeria's trade from its traditional trading partners like the United States (US) and Western Europe (WE) toward China. Recently trade between Nigeria and China has become more pronounced and has remained a channel of boosting economic cooperation between the two countries. China is top Nigeria's import origin and this has resulted in a growing trade deficit on the part of Nigeria. Despite Nigeria's effort to diversify its export to China and reduce its trade deficit, over the last decades Nigeria among its major trading partners has incurred the largest trade deficit with China. This represents a serious threat to Nigeria's efforts aimed at diversifying its export to reduce its perpetual unfavourable trade balance. Therefore, the current trend in NigeriaChina trade is not in line with Nigeria's pursuit to diversify its export to China and reduce its overwhelming deficit BOT. To this end, this study aimed to identify market opportunities that could help Nigeria increase its export to China and to lessen its deficit trade balance. This has been achieved by a series of approaches and methodologies that were proved to be vital in this kind of study as provided by empirical studies.

Our findings based on the analysis of comparative advantage revealed that Nigeria has a steady and long-term comparative advantage in cocoa and cocoa preparations, explosive; pyrotechnic matches and alloy, lac; gums, resins and other vegetables, mineral fuels, oils and product of their distillation, oilseed, oleagi fruits, grain, seed, fruit, raw hides and skins and leather and rubber and articles thereof and comparative disadvantage in aluminium and articles thereof, articles of iron or steel, cotton, electrical machinery and equipment, parts thereof; and sound recorder, fish, crustacean and other aquatic invertebrate, footwear, gaiters and the like, furniture; bedding, mattress, cushion, glass and glassware, inorganic chemical compounds and radioactive elements, man-made staple fibers, natural/cultured pearls, precious stones, metals, coin, nuclear reactors, boilers, organic chemicals, rubber and articles thereof. China enjoyed a more comparative 
advantage than Nigeria as it can potentially export to Nigeria products like articles of iron or steel, cotton, electrical machinery and equipment, explosive; pyrotechnic matches and alloy, etc., footwear, gaiters and the like, furniture; bedding, mattress, cushion, glass and glassware, inorganic chemical compounds and radioactive elements, lac; gums, resins and other vegetables, man-made staple fibers and nuclear reactors, boilers. In term of scope and potential of increasing bilateral trade relations Nigeria can competitively export to China commodities like cocoa and cocoa preparations, explosive; pyrotechnic matches and alloy, etc., lac; gums, resins and other vegetables, mineral fuels, oils and product of their distillation, oilseed, oleagi fruits, grain, seed, fruit etc., raw hides and skins and leather and rubber and articles thereof. There is little scope of increasing trade between the two countries in explosive; pyrotechnic matches and alloy, lac; gums, resins and other vegetables as they all have a comparative advantage in these products. The value of NRCA indices are negative for both countries in aluminium and articles thereof, fish, crustacean and other aquatic invertebrate, natural/cultured pearls, precious stones, metals, coin etc. organic chemicals, implying that they all have a comparative disadvantage with no scope of increasing their trade-in these commodities. But there is a greater scope of increasing their trade with other countries that have a comparative advantage in these commodities. Based on the NRCA results, there is limited scope for Nigeria to improve on its BOP as there are limited export potentials. This is because market potential only exists for Nigeria in the Chinese market in commodities like cocoa and cocoa preparations, mineral fuels, oils and products of their distillation, oilseed, oleagi fruits; miscellaneous grain, seed, fruit etc., raw hides and skins and leather rubber and articles thereof.

As a result, the study went further to identify market opportunities for Nigeria in the Chinese economy. Our findings revealed that there exist market opportunities for sixteen commodities in the Chinese economy. The study found that there exists a stable and growing market in fourteen of the identified commodities and declining market in two commodities based on average short-term growth. New markets opportunity for Nigeria in China were found in products like aircraft, spacecraft, and parts thereof, copper and articles thereof, iron and steel, optical, photo, cine, checking, precision, etc., ores, slag and ash, plastics and articles thereof, the pulp of wood/of other fibrous cellulosic mat; waste etc., vehicles railway tram and roll-stock, wood and articles of wood; wood 
charcoal. Our finding revealed that these new market opportunities in China can't all be meet by Nigeria as these commodities were either not exportable due to poor competitive position and lack of comparative advantage or due to the fact that these commodities were a highly capital-intensive product, that can only be manufactured and exported by highly capital endowed countries. Therefore, Nigeria has no comparative advantage in all of the newly identified markets/commodities. These findings provide support for studies (Ibrahim \& Iorember, 2018; Ibrahim \& Sari, 2019a) that revealed a limited scope for Nigeria to increase its export to China based on only comparative advantage. Based on the current market condition in China, for most of the commodities which Nigeria can actually and potentially export to China, we found that there are no market opportunities in these commodities. For instance, commodities like cocoa and cocoa preparations, explosive; pyrotechnic prod; matches; alloy; etc., lac; gums, resins and other vegetable saps and extracts, raw hides and skins has low market demand and there is no market opportunity for these products. Nigeria can actually and potentially export to China products like mineral fuels, oils and products of their distillation, oilseed, oleagi fruits; miscellaneous grain, seed, fruit etc., rubber and articles and there are market opportunities in these products.

Lastly, our findings revealed that Nigeria's effort aimed at increasing its export to China is limited by a lack of exportable commodities coupled with a poor competitive position. Bridging deficit trade balance will be challenging on the part of Nigeria considering the structure and competitive position of Chinese manufactured goods and long-standing position of the Chinese market in maintaining a large trade surplus with its world trading partners. To this end we offered the following policy recommendations;

The deficiency in the flow of Nigeria's export to China is a reflection of poor competitive position and at the same time a good opportunity for Nigeria to strengthen its foreign trade position based country-specific strategy. Due to the structure of Nigeria's exports which are mineral fuels and primary related products and structure of Chinese export which are manufactured goods, we, therefore, recommends the need for the relocation manufacturing firms from China to Nigeria, as this perpetual trade balance cannot be improved by weak Nigeria's primary exports. Due lack of competitive exportable commodities at HS 2 digit codes in Nigeria, the study recommends the need for Nigerian government and export promotion agency to embark on more empirical research at a more product disaggregated level (HS 6 and HS 4 digit codes) to explore 
commodities in which there are market opportunities for Nigeria in China and for which Nigeria has potential to export and bridge its BOP deficit. The government needs to also strengthen its support to the growing industries to make them more competitive globally.

\section{Reference}

Alao, A. (2011). Nigeria and the BRICs: Diplomatic, Trade, Cultural and Military Relations (O c c a s i o n a $1 \mathrm{P}$ a p e r No. 101$)$.

Amavilah, V. H. S. (2003). "'Does Trade Cause Growth?' - A Comment,."

Ayodele, T. \& Sotolo, O. (2014). China in Africa: An Evaluation of Chinese Investment (IPPA Working Paper Series (2014)).

Ayoola, T. J. (2013). Nigeria-China Trade Relations: Implication on the Nigerian Domestic Economy. Research Journal of Finance and Accounting, 4(17), 98-104.

Balassa, B. (1965). Trade Liberalisation and "Revealed" Comparative Advantage. The Manchester School of Economics and Social Studies, 33(2), 99-123. https://doi.org/10.1111/j.1467-9957.1965.tb00050.x

Benedictis, L. De. (2005). Three Decades of Italian Comparative Advantages. The World Economy, 28(11), 1679-1709.

Ekesiobi, C., Ifebi, O., Ibekilo, B., \& Onochie, J. (2011). Dynamics of Foreign Trade and Trade Relation Problems: Policy Options for Nigeria. African Research Review, 5(1), 40-56. https://doi.org/10.4314/afrrev.v5i1.64508

Eneji, et. al. (2012). Impact of foreign trade and investment on Nigeria's textile industry: The case of China. Journal of African Studies and Development, 4(5), 130-141. https://doi.org/10.5897/jasd12.004

Hammerstad, A. (2011). Nigeria and the Global Powers: Continuity and Change in Policy and Perceptions (O c c a s i o n a $1 \mathrm{P}$ a p e r $\mathrm{N}$ o. 9 6; Issue 96).

Ibrahim, K. H. (2015). Trade Complementarity and Similarity between Nigeria and India in the context of Bilateral Trade Relations. IOSR Journal of Economics and Finance, 6(6), 28-32. https://doi.org/10.9790/5933-06642832

Ibrahim K. H. \& Sayuti, A. S. (2017a). Nigeria's Export Supply versus Brazil's Import Demand: 2000-2016. Ife Social Sciences Review , 5(1), 48-58.

Ibrahim K. H. \& Sayuti, A. S. (2017b). Nigeria's Trade Complementarity and Similarity with West African Sub-Region. Benue Journal of Social Sciences, 5(1), 122-138.

Ibrahim, K. H. \& Abdulaziz, S. (2016). Nigeria-India Bilateral Trade Relations: An Analysis of Trade Complementarity Index (TCI). Asian Journal of Economic Modelling, 4(4), 190-198.

Ibrahim, K. H. \& Iorember, P. T. (2018). Sectoral and Products wise Comparative Advantage in Nigerian-China Bilateral Trade Relations. Dutse Journal of Economics and Development Studies (DUJEDS), 6(1), 110-117.

Ibrahim, K. H. \& Sari, D. W. (2019a). An Examination of Recent Trends Composition and Trade Intensity of Nigeria-BrazilBilateral Relations. International Journal of Advanced Economics, 1(1), 31-43.

Ibrahim, K. H. \& Sari, D. W. (2019b). Nigeria-China: An Examination of Recent Bilateral Trade Relations. International Journal of Applied Research in Social Sciences, 1(5), 
$172-184$

Ibrahim, K. H. \& Yusuf, M. M. (2017). Diversification of the Nigerian Economy: Prospects and Emerging Issues in the External Sector Export. In A. M. Fagge, B. G. Gumel, \& B. A. Ahmed (Eds.), Readings in Economics 2 (DIVERSIFICATION OF THE NIGERIAN ECONOMY) (pp. 284-307). Ahmadu Bello University Press Limited, Zaria, Kaduna State, Nigeria.

Ibrahim, K. H. \& Singh, D. (2014). Changing Perspective of Indo-Nigerian Trade Relations. Indian Journal of Applied Research, 4(7), 497-503. https://doi.org/10.15373/2249555x/july2014/157

Lin, J. Y. \& Monga, C. (2011). Growth Identification and Facilitation: The Role of the State in the Dynamics of Structural Change (Policy Research Working Paper No. 5313).

Nabine, D.-W. (2009). The impact of Chinese Investment and and Trade on Nigeria economic growth (ATPC Work in Progress;No.77).

Ogunkola, E. O., Bankole, A. S. \& Adewuyi, A. (2008). China-Nigeria Economic Relations, AERC Scoping Studies on China-Africa Economic Relations.

Pant, M., \& Pande, D. (2014). India-Pakistan Trade: An Analysis of the Pharmaceutical Sector (Working Paper 275).

Sen, S. (2012). International Trade Theory and Policy: A Review of the Literature. SSRN Electronic Journal, 635. https://doi.org/10.2139/ssrn.1713843 